selv om det ville være meningsløst at forsøge at ændre den hårde oplysnings logik, så er dens generelle indstilling og dens koblen sig sammen med blød "oplysning" foranderlig. Her ramler Liedman selvfølgelig ind i spørgsmålet om den bløde oplysnings eventuelle universalisme. Det ender med en forsigtig idé om, at der er elementer i den bløde (vestlige) oplysning, som ikke kan tænkes bort eller reduceres til kulturel partikularisme - uden at enhver oplysningside gøres til nonsens.

Ellers præsenteres i et upolemisk vue ganske mange modernitetsteoretiske positioner fra de sidste decennier. Godt og informativt. I det hele taget: hvis der er nogen, der har meget travlt med at sætte sig ind i Liedmans værk, så kan de koncentrere sig om afslutningskapitlet. Her er alle principielle spørgsmål stillet - til gengæld må man så undvære de mange historiske informationer. Og så kan det være, at vi er tilbage i det som det er Liedmans bestræbelse at rydde op i, nemlig modernitetsteoretiske markeringer, som trækker på en enorm historisk ballast, men som aldrig ekspliciterer den. Ved vejs ende er det klart, at Liedmans projekt ikke ender i skepticisme, fatalisme, kynisk ironi eller naiv idealisme. Han har et veludviklet blik for, at hans egne oplysningsfilosofiske idealer ofte rummer nok så megen provinsialisme. Men han har også en tro på, at der er elementer i modernitetsprojektet, som ikke kan opgives. Og som ikke bare fremsættes i skyggen af fremtiden, men som dens lys.

Bogen er oversat fra svensk af Gitte Lyngs. Og det er gjort ganske for- trinligt. En lidt dum fejl, der vel er en oversætterfejl, findes på side 444, hvor Adam Smiths metafor om "den usynlige hånd" er blevet til "den usynlige handel". Forhåbentlig er den så graverende, at læserne opdager, at noget er galt og ikke begynder at tænke $\mathrm{i}$ baner a la handel med narkotika.

Til slut et lille suk: bogen er vanskelig at læse, ikke på grund af, hvad der står i den, men fordi den som tyk limet billigbog ganske enkelt hele tiden vil klappe i - bortset fra, når man er omkring midten. Det er nødvendigt hele tiden at være over den men det er besværet værd.

Hans-Jorgen Schanz.

\section{Se Venedig og tænk videre!}

Christian Bank Pedersen: Formens erindringer. Om Thomas Manns Der Tod in Venedig, Skriftserien LAS, Klim 2001, 160 sider, 198 kr.

Det siges, at i Venedig har der altid været nogen, der har skabt kunst, før man selv indfinder sig. Man kan kunstnerisk set kun i svarets form træde ind i Venedig. Det gælder også Thomas Manns Døden i Venedig og i en fordobling forfatteren Aschenbachs ageren i selvsamme roman - og nu tillige Christian Bank Pedersen der skriver en bog om Aschenbach i Venedig, der er om Mann, der skriver i og om Venedig osv., der dog også er om stemmerne "fra det fjerne": Platon, Schopenhauer og Nietzsche. 
Problemet er imidlertid, at Venedig er en syg by, og at byens indre forvirring kan tage magten over én, fordi man hvad mange helt bogstaveligt har oplevet - kan fare vild $i$ byens labyrinter, $o g$ at man, selv når man tror at være kommet ud af labyrinten, $i$ en anden forstand kan vikles endnu stærkere ind i den. Det er ifølge Bank Pedersen, hvad der sker med Manns Døden i Venedig, og det ikke kun sker, der er ligefrem tale om, at Mann bevidst indarbejder kunstens muligheder og begrænsninger i fremstillingen. På den måde er der en tendens til, at værket og læsningen af værket - lukker sig om sig selv. Kunstværket bliver som Venedig uden grund, og det kan kun leve af fortidens billeder, der ligger lag på lag. Altså: I Venedig er "Erinnerung" den eneste mulighed for formning af litteratur, fordi genlydene her er uundgåelige. Derfor titlen på nærværende bog: Formens erindringer.

Denne fiksering på erindringen, det altid allerede skabte, fører til en forherligelse af nogle bestemte bevægelsesmønstre i læsningen med forfaldet, parodien og i bedste fald humoren $i$ focus. Bogen er da også gennemsyret af sætninger som: "For i og med dette forfald og denne destruktion kommer i fortællingens optik også, og ikke mindst, netop litteraturens krav til sig selv - og dens nødvendige tilbøjelighed for sig selv - til syne. Forfaldet og tabet er måske endda for Der Tod in Venedig litteraturens tilgrundliggende billede: $i$ sidste instans det litterære værks humoristiske tvivlende længsel efter evig, primær form - og dermed faktisk også det litterære spejls fordækte glæde ved sig selv og sine egne afledte gengivelser" (s. 10). Eller med nogle andre ord: "Parodien er kærlighed til en kunstform, som man ikke længere tror på (...) Kultur er kærlighed og parodi, dvs. læsning af ens forbilleder..." (s. 18). På den måde befinder vi os hele tiden i en "bevægelse mellem betydning og betydningsløshed" (s. 58) "et sted mellem ingenting og noget" (s. 92), "ingenting er ligegyldigt hvad" (s. 59). Selv for den bedste kunstneriske kreativitet er der ikke andre muligheder end at bygge på længslen og den uoprettelige tabsoplevelse.

Spejling, selvspejling, komiske grimasser, klage uden sorg, parodi, sågar en "over-skrivende parodi”" bliver de forløsende ord i denne "forståelsens komedie". Vi kender det alt sammen, for det er litteraturens tilbøjelighed for sig selv. Når det drejer sig om Døden i Venedig, må det siges at blive til for meget spejl og for lidt gejl, dvs. for lidt af det dionysiskes amorfe karakter. Derfor er det ikke, som hævdet af Christian Bank Pedersen, det eneste genuint tragiske ved historien om Gustav von Aschenbachs rejse i Venedig, at læse Døden i Venedig med centrum i forestillinger som patos, tragedie og æsteticismens skæbnesvangre dekadence og undergang, for uden dén form for læsninger ville der måske blot have været en tekst for lærerne, der skal lære om tekster. Hvad der selvfølgelig ikke er så tosset for lærerne, men det er ikke tilstrækkeligt for os Mann-læsere som sådan, for i Døden i Venedig ér der vitterlig tale om patos, tragedie og æsteticismens skæbnesvangre dekadence og undergang. 
Når det nu er sagt, skal det videre frem påvises, hvorfor og hvordan der med Bank Pedersens bog er tale om en fremragende tekst, der kan give utrolig mange perspektiveringer om Døden i Venedig, ikke mindst hvad angår de "fra det fjerne" medtalende tænkere: Platon, Schopenhauer og Nietzsche.

Platon forbindes med Mann i forhold til tre problemstillinger: eros, anamnesis og mimesis. Eros-problematikken synes indlysende, da Døden i Venedig netop handler om længslen efter den tabte form. Udgangspunktet er: "Uden tab ingen erotisk længsel: den perfekte Form lider ingen mangel". Men da mennesket ifølge Platon er et mangelfuldt væsen, må det søge efter det tabte, dvs. det må forsøge at erindre det, for platonisk betragtet er erindringen, anamnesis, den eneste mulighed. Det foregår i en bevægelse fra anskuelsen af den ydre forms skønhed til den indre opstigning mod de højeste formers evige, forandringsfri kosmos, hvor pointen er, at tabet $i$ en vis forstand ikke ligger udenfor mennesket, men i mennesket, idet man begærer den sande væren i sig selv. I Manns optik, der i det væsentlige er parodisk, bliver det til en i særlig forstand af-idealiseret platonisme: "En filosofisk eros, med omvendt fortegn, der er litteraturens egen iboende og leende længsel efter litteraturens perfekte Form" (s. 19). Det er en kærlighed til en form, der altid allerede er tabt. Derfor parodien. Platon er værkets filosofiske original, fordi han selv var bogstavelig bevæget af længslen efter det tabte - som filosof. I Døden i Venedig er
Mann - idet filosofien til et vist punkt gøres som om den var litteratur, og litteraturen forvandles til filosofisk ambition - således i mimetisk dialog med Platon, fordi bestræbelsen angår, eller er, den erotiske længsel: I begyndelsen var begæret efter den oprindelige og altid tabte form (s. 42f).

Det er dog især hvad angår den platonisk inspirerede kantianske filosof Schopenhauer, at der forefindes en guldgrube af tankevækkende overvejelser i Formens erindringer. Schopenhauer er da også den eneste tænker, der får en selvstændig præsentation, og omtalen af ham fylder rent kvantitativt mest (s. 75-119).

Med afsæt i Verden som vilje og forestilling sættes Mann og Schopenhauer $i$ forhold til hinanden, fordi sidstnævnte har set tilværelsens og ikke mindst den kunstneriske formidlings (og skabelses) problemer, at ville meddele sig fra og $\mathrm{i}$ en verden, der $\mathrm{i}$ sig selv synes at være intet. Vi har blot en bevidsthed, der paradoksalt er frembragt af viljens bevidstløse villen, men som ikke desto mindre siger, at "verden er min forestilling". Verden er egentlig ren vilje, der kun i forestillingen kan fremtræde som noget, dvs. som erkendelsens muligheder. Men det er ikke erkendelsens muligheder, der her har specifik interessse. Interessen er derimod det punkt, hvor den menneskelige bevidsthed formår at se igennem viljens spil og dens former, og ligefrem reflekterende ønske det, hvor der ingen vilje er, dvs. Intet. Det er det samme som at se bag om Mayas slør. Sløret er Erscheinung, fænomenerne, fremtrædelserne. Men intellektet kan 
se bag om Mayas slør, og dermed i sandhed komme til sig selv. Den ikkeseende vilje - altings fundament, alting, slet og ret - afstedkommer altså en udfoldelse, der fører til viljens egen fornægtelse. Igennem denne fornægtelse føres mennesket frem til et Intet, som er noget, fordi det ganske simpelt, som Intet, er den i sidste instans eneste ægte opfyldelse. Det bliver via den totale resignation, askesen, til en Mitleid - en med-liden i den kval, som verden er. Her overskrides enhver form for subjektivitet og bevidsthed, og maya opløses i en fuldstændig befrielse. Det er nirvana. Havblik (s. 82).

Et af paradokserne for Schopenhauer er imidlertid, at han som forfatter er nødt til at bekræfte netop dét synlige, han og vi må se igennem, for at kunne punktere det. Man må sætte sin grund i det, der ikke tæller som grund. Det er en form for fremtrædelsernes fordobling, hvilket fører frem til en kobling til Platons kunstner, der er to skridt fra det egentlige, ideerne, dvs. skaber et billede af billedet. Det er præcis dette forhold, Bank Pedersen reflekterer, idet han påpeger, at Aschenbach $\mathrm{i}$ Døden i Venedig som forfatter skriver på en roman, der bærer navnet Maja. Aschenbach er som forfatter schopenhauerisk dannet, fordi han "ses $i$ skygge af en idé, som er en skygge af en idé" (s. 88). Aschenbach har netop i sin roman samlet menneskeskæbner i sig under titlen Maja, og det er som Schopenhauer siger, menneskeverdens mangfoldighed som skin.

Problemet er herefter blot, at kunsten for Schopenhauer er en væsensskuen, dvs. en uinteresseret, begærsfri betragten af de tidløse ideer, men at Aschenbach ikke skuer verdens inderste væsen, dvs. han kommer aldrig uden for skyggens domæne. Der er tale om blændværk, og når der ikke skrives mere, når sløret falder, så bliver der Intet tilbage. Dette Intet bliver hos Mann, som den skabende kunstner han er, til romanen Døden i Venedig, hvorefter vi har: "Et fænomenalt og formfuldendt Intet eller en platonisk-schopenhauerisk væsensskuen?” (s. 90). Efter Bank Pedersens mening er der hos Mann tale om, at han opfatter Schopenhauers egen tænkning som selvcirkulerende: den praktiserer, hvad den forestiller sig. Ikke mere, intet mindre. Derfor er den: "skabelse af sandhed: poiesis, snarere end platonisk væsensskuen i traditionel forstand" (s. 94). Men som allerede antydet: For at kunne sætte sig selv i en position, hvorfra han kan afsløre det bedrag, som verden er, er Schopenhauer nødt til at bekræfte bedraget ved at anvende en af bedragets former, samtidig med at det også gælder, at enhver form for umiddelbar anskuelig erkendelse kun kan udfolde sig med forstandens hjælp, dvs. når man skal meddele denne viden, bliver man nødt til at fiksere den $i$ nogle begreber. Det er her, latteren kommer ind.

Latterens natur er funderet $i$ erkendelsen af en inkongruens mellem en abstrakt tanke og en faktisk situation: "Latteren måler hos Schopenhauer altid distancen mellem begrebet og den virkelighed, det hævder at fremstille i en perfekt dækkende tanke" (s. 107). Det handler om det fundamentalt problematiske i, at tænkningen for- 
søger at be-gribe verden. Her træder latteren til og blotlægger ordenes utilstrækkelighed og begrebsliggørelsens megalomani: Ordet kommer altid til kort, og besidder man virkelig filosofisk storhed, ler man med verden: "Jo større inkongruens, jo højere latter" (s. 108). Hvor der er ord, er der inkongruens, og derfor bør der altid være latter, synes Schopenhauer at sige, for fornuftens begreber slår aldrig til. Derfor er det også lattervækkende at ville fastholde det uendeligt nuancerede $i$ ét ord, som fx latter. Men det er det eneste, der kan gøres, og derfor har vi latteren: "Ordene ler i deres umulige bestræbelse på at gribe, fastholde og efterligne den latter, der tilsyneladende ikke vil andet end sin egen uendelige reproduktion, hvilket naturligvis er løgn, eftersom latter vel netop også er anskueligt uigentagelig. Sandhed 'uden sprog' kaldes latteren hos Per Højholt" (s. 114). Filosoffen kan således kun le, idet han fordobler sit sprogs blændværk i en tænkning, der muligvis repræsenterer pessimisme og sortsyn, men altså som sort også er latter. Anderledes sagt: Humorens latter i formens forsvindingspunkt: "I Schopenhauers tekst Die Welt als Wille und Vorstellung ler filosoffen øjensynligt af sin egen filosofiske bestræbelses form. I Der Tod in Venedig er der ingen, der ler, hvilket naturligvis vil sige, at der i dette værk egentlig ikke forefindes nogen latter, der når ud over kunsten, forstået på den måde, at der i fortællingen i særlig henseende ikke gives nogen latter ud over kunstens (s. 118). Det er forfatteren Thomas Manns filosofiskerotiske tilbøjelighed for den æsteti- ske frembringelse, der som byen Venedig har sit fundament i havet, dvs. sin grund i en ugrundet bevægelig form: "Form og formløshed hører i værkets optik i sidste instans uopløseligt sammen. Værket selv er et klæde ophængt over ingenting, et Majas slør, men altså netop uomtvisteligt et klæde: Noget der 'dækker' over Intet' (s. 57). I Døden i Venedig viser det sig, at Aschenbach ikke kun er på sporet af den skønne, men også er i sporene af det skønne, det spor, der er praget $\mathrm{i}$ Venedigs labyrint længe før Aschenbach ankommer til byen, og som ikke kan bemestres af det individuelle begær. Tværtimod bemestrer og overskriver skønhedens spor det personlige i en uundgåelig desubjektivering. Man fordyber sig ikke i stadens indre, men forsvinder snarere i denne ustyrlige midte (s. 123). Det højeste man kan er at bevæge sig skabende omkring $i$ en formernes labyrint, som man ikke har kontrol over, som det påvises i en analyse af Nicholas Roegs film Don't look now (s. 124).

Først herefter kommer den tredje af stemmerne fra det fjerne, Nietzsche, rigtig på banen, og det må siges at være en rigtig prioritering, uanset hvor fristende det kunne have været at inddrage ham undervejs, for det ville have forplumret eller gjort spændingerne mellem Platon, Schopenhauer og Mann uoverskuelige. Nietzsche kommer med et bud på det problem, hvordan det overhovedet er muligt at tale og sige sig selv igennem Venedigs genlyde, dvs. i traditionens ekkorum (s. 127ff). Det fordrer et nyt jeg, et mig, der accepterer at gå ud over 
sig selv i traditionel forstand, hvilket fordrer en lytten, som Bank Pedersen læser ud af Nietzsches digt om Venedig: "Subjektet går ud fra sig selv, og går ud over sig selv, idet det bliver instrument for et svar, som igen rummer muligheden for en gestaltning af en anden subjektivitet" (s. 131). Selvfremstilling er samtidig selvovervindelse. Her bevæger vi os fra Venedig til musikken, og til en endnu mindre fast form, en form der ikke er totalt ophævet, men er åben for transformationer. Det har at gøre med det værendes dybeste regioner, som tænkningen ikke kan række ind i, men kun kunsten kan forholde sig til, der for Nietzsche hovedsagelig er det samme som tragediens metafysiske trøst - "det tragiskes lidende Heiterkeit” (s. 135). For man kan ikke se - heller ikke dialektisk a la Sokrates - tingenes væsen, men man kan få en dennesidig trøst som både forfatter og læser, latterens trøst i kunstens bedrag.

Hermed skulle det være tydeligt, at al visdom egentlig er en forbrydelse mod naturen, der, som forskellige former for Majas slør, skaber illusorisk kultur i en hvirvel af fremtrædelser, der gemmer det evige livs udestruerbare viderestrømmen (s. 135). Den indre sandheds skjulte skønhed er der slet ikke, som ethvert sokratisk menneske ellers forstiller sig, der er kun formernes ustandselige "Erinnerung", der i bedste fald som æstetisk form er værkets vedvarende enteleki, dvs. dets liv og formgivende kraft.

Det skal sluttelig tilføjes, at Bank Pedersen også analyserer ledemotiver og tematisk specifikke elemen- ter fra Døden i Venedig som rejselyst, døden og tænder såvel som personifikationerne vandreren, den berusede olding, gondolieren, bajadsen og selvfølgelig ikke mindst Tadzio. Derudover indeholder bogen en række koblinger både til Manns øvrige forfatterskab og en række andre tænkere: Goethe, Kierkegaard, Barthes, Benjamin, Højholt m.fl. Men først og sidst anskues en tekst i nærværende bog som et eksempel på den intellektuelles (Bang Pedersen) forståelse af forfatterens (Mann) latterlige kærlighed til kunstnerisk form (Døden i Venedig) der ytrer sig i selve værket (Aschen-bach m.v.). Der er nok at tage fat på, idet der her også er noget der forekommer, en tekst der lægger sin form bag sig - endda uden stavefejl!

\section{Ole Morsing}

\section{Paul Ricœurs filosofi}

Jacob Dahl Rendtorff: Paul Ricœurs filosofi, Hans Reitzels Forlag 2000, 184 sider, 198 kr.

I serien FilosofiBiblioteket har Hans Reitzels Forlag udgivet en introduktion til den franske filosof Paul Ricœurs (f. 1913) tænkning. Bogen, som bærer den enkle titel Paul Ricœurs filosofi, er skrevet af Jacob Dahl Rendtorff, der er adjunkt ved Institut for samfundsvidenskab og erhvervsøkonomi ved Roskilde Universitetscenter. Jacob Dahl Rendtorff har tidligere bidraget til Reitzels serie med bogen Jean Paul Sartres filosofi (1998), ligesom han har skrevet indledningen til udgivelsen af 